\title{
Interferon Regulatory Factor 8
}

National Cancer Institute

\section{Source}

National Cancer Institute. Interferon Regulatory Factor 8. NCI Thesaurus. Code C104556.

Interferon regulatory factor 8 ( $426 \mathrm{aa}, \sim 48 \mathrm{kDa}$ ) is encoded by the human IRF8 gene.

This protein plays a role in the regulation of gene transcription. 